UNIVERSITY OF CHITRAL JOURNAL OF LINGUISTICS AND LITERATURE

VOL. 5 | ISSUE I | JAN - JUNE | 2021

\title{
A Discourse Approach to Spoken and Written Narratives: Pedagogical Implications for EFL Learners
}

\author{
Ms. Qurrat-ul-Ain \\ Department of English, National University of Modern Languages, Islamabad \\ Dr. Yasir Hussain \\ Department of English, National University of Modern Languages, Islamabad \\ Dr. Fasih-ur-Rehman \\ Department of English, Khushal Khan Khattak University, Karak
}

\begin{abstract}
Recent research on the analysis of spoken discourse (Halliday, 1985, McCarthy, 1998) shows that spoken language also has a consistent structure and in many respects, it does have the language patterns as that of written English. Thus, it proves that both spoken and written language have a describable structure. The aim of this study is to explore some discourse features of both spoken and written English and their pedagogical implication. For this purpose, two texts: a spontaneous speech (recorded and transcribed) and then a short-written poem are analyzed at both micro and macro level of discourse. As both texts have narrative content, Labov's model of narrative analysis is applied to identify their organizing pattern. Similarities and differences in the discourse features of both texts are also examined. Some pedagogical implications of such an analysis are also suggested to language teachers; so that they can improve students' language competence skills by adopting discourse-based teaching strategies.
\end{abstract}

Keywords: discourse, pedagogy, EFL learners, written discourse

\section{Introduction}

Richard Nordquist (2014) defines Discourse Analysis as "the study of the ways in which language is used in texts' contexts". It developed in the 1970s, discourse analysis "concerns itself with the use of language in a running discourse, continued over a number of sentences, and involving the interaction of speaker (or writer) and auditor (or reader) in a specific situational context, and within a framework of social and cultural conventions" (M.H. Abrams and G.G. Harpham, A Glossary of Literary Terms, 2005). In Linguistics, it is used to define a language which is beyond the level of sentence. Discourse Analysis (DA) is a modern discipline of the social sciences that covers a wide variety of different approaches related to applied linguistics and language education such as sociology: conversational 
UNIVERSITY OF CHITRAL JOURNAL OF LINGUISTICS AND LITERATURE

VOL. 5 | ISSUE I | JAN - JUNE | 2021

analysis (Schegloff and Sacks, 1973) Sociolinguistics: ethnography (Hymes, 1974), variation theory by Labov (1972), Philosophy: Speech act theory (Austin, 1962) Education classroom discourse (Sinclair and Coulthard, 1975), linguistics: Systemic functional linguistics (Halliday, 1976)

All these approaches have made a significant contribution to the understanding of discourse. The present study, however, focuses on the Labov's research on narrative within Variation Theory. The researcher took two texts of spoken and written English, analysed their micro and macro level features. As both texts have narrative content, therefore, Labov's description of the narrative analysis has been applied.

Labov states (1972) that the 'overall structure' of a fully formed narrative of personal experience can be divided into six elements: abstract, orientation, complication, evaluation, resolution and coda. The researcher used these six elements as explained by Labov, and then applied at the both texts for their macro level analysis.

\section{Literature Review}

\subsection{Abstract}

This is the optional element in the story at the beginning which summarizes the entire story. Bell (1991) believes "that an abstract is not obligatory in narrative writing. The writer has the "option whether to include an abstract or not in writing his narrative". Abstract not only tells the audience what the story is about but also summarizes the purpose of the story as well.

\subsection{Orientation}

(Labov, 1972) defines that "the orientation identifies the place, time, characters, and their activities and is usually introduced at the onset of stories". It is normally narrated in past progressive tense to make the audience understand the narrated events. Labov also emphasizes on the 'placement' of orientation by saying "it is theoretically possible for all free orientation clauses to be placed at the beginning of the narrative, but in practice, we find much of this material at strategic points later on". (pp. 364-365). If mentioned later in the narrative, it can serve the purpose of both as an evaluation or create suspense by suspending the resolution. 
UNIVERSITY OF CHITRAL JOURNAL OF LINGUISTICS AND LITERATURE

VOL. 5 | ISSUE I | JAN - JUNE | 2021

ISSN (E): 2663-1512, ISSN (P): 2617-3611

\subsection{Complication}

This is the longest part of the narrative, consisting of temporal sequence of events and culminating the action. It may embed orientation and evaluation. Junqueira (2010) states "it is the backbone of the story formed by the sequence of narrative clauses that reports a next event in response to a potential question" As labov defines "And what happened then?" Afsar (2008) argues that complicating action may have various other types of clauses e.g. free and evaluative to describe the narrative action.

\subsection{Evaluation}

According to Labov (1972), "evaluation is one of the most important aspects of stories because it is used by the narrators to indicate the point of the narrative, its raison d'être: what it was told, and what the narrator is getting at" (p. 366). Evaluation is narrator's attitude towards narrative and a good narrator knows how to keep his audience attentive by narrating interesting, unusual parts of the story. Afsar (2008) states that evaluation as an effective component of narration operates at both macro and micro level of the text.

\subsection{Resolution}

This element of narrative focuses on "what finally happened". Junqueira (2010) states that "it often starts with the last narrative clause of the complicating action, explaining how the complication was solved" it finally releases the suspense.

\subsection{Coda}

Coda is also an optional element; it points about narrative as a whole. Codas appear in free clauses at the end of the story, signal the end of the story as well. They intend to return from the narrative time to present as Afsar (2008) states that "by means of a coda, the narrator can bridge the gap between the end of the story and the present."

\section{Research Methodology}

The following section presents the spoken and written text, which is analyzed at both micro and macro level, similarities and differences in discourse features of both texts are also examined.

\section{Text 1: Spontaneous speech by Fasih}


UNIVERSITY OF CHITRAL JOURNAL OF LINGUISTICS AND LITERATURE

VOL. 5 | ISSUE I | JAN - JUNE | 2021

ISSN (E): 2663-1512, ISSN (P): 2617-3611

Fasih is the co-researcher, who was requested to narrate an interesting recent event. He was kind enough to accept the request. This conversation took place at co-researcher's own home, when Fasih was asked to narrate the event. The researcher recorded this spontaneous speech in her cell phone and then transcribed later. The conversation started with the question of the researcher:

Researcher: SO, what are you going to tell me?

Fasih: umm...well..it's about my recent flight to Gilgit.

Researcher: OK, is it funny or interesting?

Fasih: well...you can say..it;s both...

Researcher: Ok, let's start then...

Fasih: Ok.

Text 1: Transcribed Passage

My flight to Gilgit

Ok..that was basically the morning of $4^{\text {th }}$ April, this month..I had to leave to Gilgit in order to start an assignment of 15 days there...SO...IT was I think..it was around 9..8..8.. in the morning..I left for the airport and I reached the...airport around 9 ... from 9 uptill.. 10..I waited and then the flight was announced...so...I boarded on the plane..We.. took off.. and..we started towards Gilgit..and we ma..made a flight of..I think 45 minutes..th.th..the aeroplane CRew.. they served us with some eatables and..in the beginning I was not really willing to have something to eat or drink..but ultimately after 40 minutes.. of flight I started taking my... a..small little burger with a biscuit and..one banana..and then... all of a sudden this..CAPtan announced that ladies and gentlemen we don't have the possibility to land in Gilgit so we are going BACK.. That was for ME. Because that was my First Ever FLIGHT and the First ever flight to Gilgit as well..and..I was enjoying...hh..view..out:side... We came back. I came BACK home. 
UNIVERSITY OF CHITRAL JOURNAL OF LINGUISTICS AND LITERATURE

VOL. 5 | ISSUE I | JAN - JUNE | 2021

For next Three days...I continuously visited airport...and..flights got cancelled...and..th..th..this was really disappointing for me..I have no possibility to reach Gilgit..and..I don't know for how long will I continue to... keep visiting the airport ... and missing my flights..or not in fact missing my flights but having them cancelled ..or not having the possibility to reach my destination... or... or tomorrow I will be going once again...or even day after tomorrow ...let's see how it goes...(unhhm)

Researcher: Keep your fingers crossed...and thank you very much.

Fasih: My pleasure!

\subsection{Key used for the Transcription}

The transcription techniques were devised by Gill Jefferson, however in transcribing text 1 , the researcher used transcribing conventions which are adapted from Van Dijk (1997).

\subsubsection{Punctuation}

Full Stops: $\quad$ for pauses, one for a short pause, two or three for longer pauses.

Capital letters: $\quad$ for proper names.

Colons: for prolonged syllables.

Capitalization: for highly stressed syllables

Non verbal Sounds: into brackets.(sniffs)

Indecipherable: words which are not clear are put in the brackets.

Breathing indicators: marked by hh, a period followed by hh marks an inhalation.

\subsection{Analysis at a Micro Level}

The conversation took place at the co-researcher's home. The researcher requested the co-researcher to narrate an interesting event from his life which will be recorded for an analysis. The conversation held in the drawing room of the co-researcher's home which was 
UNIVERSITY OF CHITRAL JOURNAL OF LINGUISTICS AND LITERATURE

VOL. 5 | ISSUE I | JAN - JUNE | 2021

vacant and there was no interruption at the time of recording. Therefore, no interference can be observed in the transcription. However, when the conversation ended, both narrator and narrattee checked the audio recording to avoid any problem in retrieving the data for the analysis.

There are several spoken features at micro level which can be observed in this transcribed spoken text.

Table 1: List of Features of Spoken Language

\begin{tabular}{|c|c|}
\hline Features & Examples \\
\hline Cohesive Devices & $\begin{array}{l}\text { So (L,2,5), Then( L, 10), Because } \\
(\mathrm{L}, 13) \text {, Or }(21,22)\end{array}$ \\
\hline Contractions & $\begin{array}{l}\text { Don't (L,11,19), Didn't (15), Let's ( } \\
\text { 23) }\end{array}$ \\
\hline Co-ordination & $\begin{array}{l}\text { "And" has been used } 10 \text { times, as } \\
\text { the most frequent spoken feature in the } \\
\text { text. }\end{array}$ \\
\hline Delexical Vebs & $\begin{array}{l}\text { Have(L,8,11), Made ( L,6), Taking } \\
\text { (9) }\end{array}$ \\
\hline Dexis & That (L,1), This( L,1,11,13) \\
\hline Discourse Markers & Ok $(\mathrm{L}, 1)$ \\
\hline False Starts & $\begin{array}{l}\text {..it was around 9..8..8.. in the } \\
\text { morning }(L, 3)\end{array}$ \\
\hline Fillers & Ma...Ma (L,6,18), Th..Th (L,7) \\
\hline Less Grammatical Sentences & $\begin{array}{l}\text { I started taking my... a..small little } \\
\text { burger with a biscuit and..one banana } \\
(\mathrm{L}, 10)\end{array}$ \\
\hline Repitition & the digit 8 is repeated in $(\mathrm{L}, 3)$ \\
\hline Sentence Adverbial & $\begin{array}{l}\quad \text { Basically( L, 1), Really (L,8), } \\
\text { Continuously (L,16), Even (L,22), } \\
\text { Ultimately (L,9) }\end{array}$ \\
\hline
\end{tabular}

In the next section, the researcher chose a written narrative text and analysed its characteristics at both micro and macro level.

Text 2: Poem

The Road Not Taken by Robert Frost 
UNIVERSITY OF CHITRAL JOURNAL OF LINGUISTICS AND LITERATURE

VOL. 5 | ISSUE I | JAN - JUNE | 2021

Two roads diverged in a yellow wood, And sorry I could not travel both And be one traveler, long I stood And looked down one as far as I could

To where it bent in the undergrowth;

Then took the other, as just as fair And having perhaps the better claim, Because it was grassy and wanted wear; Though as for that, the passing there Had worn them really about the same,

And both that morning equally lay In leaves no step had trodden black Oh, I kept the first for another day! Yet knowing how way leads on to way, I doubted if I should ever come back.

I shall be telling this with a sigh

Somewhere ages and ages hence:

Two roads diverged in a wood, and I,

I took the one less traveled by,

And that has made all the difference.

\subsection{The Road Not Taken: Analysis at a Micro Level}

Some characteristics of written language are summarized in the following table:

Table 2: List of Features of Written Language

\begin{tabular}{|l|l|}
\hline Features & Examples \\
\hline Non -Finite Clauses & $\begin{array}{c}\text { Passing (L,9), Knowing(L,14), } \\
\text { Telling (L,16) }\end{array}$ \\
\hline Relative clause & That (L,5), Where (L,20) \\
\hline Cohesive Devices & $\begin{array}{l}\text { Then (L,6), Because (L,8), Though } \\
(\mathrm{L}, 9)\end{array}$ \\
\hline Adverbial Clause & $\begin{array}{c}\text { As far as }(\mathrm{L}, 4), \text { As just as(L,6), If } \\
(\mathrm{L}, 15), \text { Because }(\mathrm{L}, 8)\end{array}$ \\
\hline
\end{tabular}


UNIVERSITY OF CHITRAL JOURNAL OF LINGUISTICS AND LITERATURE

VOL. 5 | ISSUE I | JAN - JUNE | 2021

ISSN (E): 2663-1512, ISSN (P): 2617-3611

\begin{tabular}{|l|c|}
\hline Co-ordination & $\begin{array}{c}\text { And, being the most frequently used } \\
\text { feature, has been used for } 7 \text { times in the } \\
\text { poem. }\end{array}$ \\
\hline Fronting & $\begin{array}{l}\text { be one traveler, long I stood }(\mathrm{L}, 3) \\
\text { both that morning equally lay }(\mathrm{L}, 11)\end{array}$ \\
\hline
\end{tabular}

\subsection{Comparison of Both Texts at Micro Level}

Table 1 and 2 show features of spoken and written language at micro level, though not comprehensive, but a representation of some aspects of both spoken and written English language.

Table 1 shows that spoken text gives less dense information, it is informal, unplanned, interactive and ideas are less logically organized. As it is a spontaneous speech, it is replete with pauses and fillers. Narrator stresses to emphasize the particular words, low and high intonation patterns and some breathing indicators are also there. Sometimes repetition, self correction, false starts are also observed. Such features differentiate spoken texts from that of written text.

Table 2 shows the features of written text which is well planned, organized and the information is very densely packed in. Relative clauses, Non finite verbs and cohesive devices are also found in the written text.

As the written text is also a narrative poem, therefore it shares some features of spoken language as well. Both texts have co-ordination "and" which occurred most frequently. Personal pronoun "I" has also been used in both narrative texts. Linkers are also used in both texts as well as discourse markers. Both texts have narrative clauses which have simple

\subsection{Analysis at a Macro-level: Narrative Structure}

Both spoken and written texts have been structurally organized and compared at macro level by applying the Labov's modal of narrative analysis.

Table 3: Comparison of Spoken and Written Narratives

\begin{tabular}{|l|l|l|} 
Narrative Structure & Text 1: A spontaneous & Text 2: A poem \\
\hline
\end{tabular}


UNIVERSITY OF CHITRAL JOURNAL OF LINGUISTICS AND LITERATURE

VOL. 5 | ISSUE I | JAN - JUNE | 2021

ISSN (E): 2663-1512, ISSN (P): 2617-3611

\begin{tabular}{|c|c|c|}
\hline & speech & \\
\hline Abstract & $\begin{array}{l}\text { [Conversation before } \\
\text { the narration starts] } \\
\text { Researcher: SO,what } \\
\text { are you going to tell me? } \\
\text { Fasih: umm... well..it's } \\
\text { about my recent flight to } \\
\text { Gilgit. }\end{array}$ & $\begin{array}{l}\text { [The title] the road } \\
\text { not taken }\end{array}$ \\
\hline Orientation & $\begin{array}{l}\text { [time, place and } \\
\text { situation is distributed } \\
\text { from L1 to L5] ..that was } \\
\text { basically the morning of } \\
4^{\text {th }} \text { April }(\mathrm{L}, 1) . .8 . . \text { in the } \\
\text { morning..I left for the } \\
\text { airport and I reached the } \\
\text { airport around } 9(\mathrm{~L}, 4)\end{array}$ & $\begin{array}{l}\text { Two roads diverged } \\
\text { in a yellow wood }(L, 1)\end{array}$ \\
\hline Complicating Action & $\begin{array}{l}\text { [sequence of temporal } \\
\text { actions have also been } \\
\text { distributed] some } \\
\text { examples of narrative } \\
\text { sequence are: I boarded on } \\
\text { the plane..we took off.. } \\
\text { and..we started towards } \\
\text { Gilgit..and we ma..made a } \\
\text { flight of..I think } 45 \\
\text { minutes(L,6) ... all of a } \\
\text { sudden this..CAPtan } \\
\text { announced that ladies and } \\
\text { gentlemen we don't have } \\
\text { the possibility to land in } \\
\text { Gilgit so we are going } \\
\text { BACK(L,11) }\end{array}$ & $\begin{array}{l}\text { And sorry I could not } \\
\text { travel both(L,2) } \\
\text { And be one traveler, } \\
\text { long I stood(L,3) } \\
\text { And looked down one as } \\
\text { far as I could }(\mathrm{L}, 4) \\
\text { To where it bent in the } \\
\text { undergrowth; }(\mathrm{L}, 5) \\
\text { Then took the other(L,6) } \\
\text { Oh, I kept the first for } \\
\text { another day!(L,13) }\end{array}$ \\
\hline Evaluation & $\begin{array}{l}\text { That was for ME. } \\
\text { Because that was my First } \\
\text { Ever FLIGHT and the } \\
\text { First ever flight to Gilgit } \\
\text { as well..and..I was } \\
\text { enjoying...hh...view }\end{array}$ & $\begin{array}{l}\text { Yet knowing how } \\
\text { way leads on to way, } \\
\text { I doubted if I should } \\
\text { ever come back.(L,15) }\end{array}$ \\
\hline
\end{tabular}


UNIVERSITY OF CHITRAL JOURNAL OF LINGUISTICS AND LITERATURE

VOL. 5 | ISSUE I | JAN - JUNE | 2021

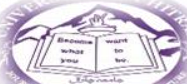

ISSN (E): 2663-1512, ISSN (P): 2617-3611

\begin{tabular}{|l|l|c|}
\hline & outSide...(L,14) & \\
\hline Resolution & $\begin{array}{c}\text { I came BACK } \\
\text { home.(L,15) }\end{array}$ & $\begin{array}{c}\text { I took the one less } \\
\text { traveled by }(\mathrm{L}, 19)\end{array}$ \\
\hline Coda & $\begin{array}{c}\text { let's see how it } \\
\text { goes...(L,22) } \\
\text { and the closing } \\
\text { conversation can as also } \\
\text { be considered as coda. }\end{array}$ & $\begin{array}{c}\text { And that has made all } \\
\text { the difference.(L,20).LK }\end{array}$ \\
\hline
\end{tabular}

Table 3 clearly draws the comparison between spoken and written narrative, highlights the labovian characteristics of narrative.

Both narratives have an abstract, though in the spontaneous speech it occurs during conversation, when the narrator mention about his "flight to Gilgit" which took place before the actual narration started. However, in the written poem, the title "The road not taken" tells us about the poem, it answers the question that what will be told in the poem.

As Afsar (2008:10) mentions that orientation occurs before the first narrative clause, identifies the time, place and situation of the event. In both texts orientation has been defined e.g. when the narrator tells about time when he left for the airport, even date is also mentioned "that was basically the morning of $4^{\text {th }}$ April...8.. in the morning..I left for the airport". Similarly, the poet also mentions the place "Two roads diverged in a yellow wood".

Complicating action consists of temporal sequence of events which culminates the main events in simple past form and lead up to the maximum sequence of the events as explained by Junqueira (2010:18). Text 1 shows distribution of complicating action throughout the speech. Some examples are; "left", "reached" "waited”, “ announced", “ boarded", “ took", " started”, "served" "announced". Text 2 also answers the question "what happened then" by using narrative clauses in simple past e.g. "could", "stood", "looked", "bent", "took", "kept".

Next element evaluation is the most important part of a narrative, which shows the narrator's attitude towards narrative. Junqueira (2010:19) states that "evaluation draw attention to interesting aspects or the story or unusual parts; in this way, the audience keeps listening and it allows the narrator to continue telling his/her story". Text 1 has been evaluated 
UNIVERSITY OF CHITRAL JOURNAL OF LINGUISTICS AND LITERATURE

VOL. 5 | ISSUE I | JAN - JUNE | 2021

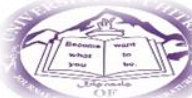

ISSN (E): 2663-1512, ISSN (P): 2617-3611

when the narrator comments "That was for ME. Because that was my First Ever FLIGHT and the First ever flight to Gilgit as well..and..I was enjoying...hh..view outside...”. Text 2 also gives the instance of evaluation when narrator mentions about the choices he had been given, "Yet knowing how way leads on to way, I doubted if I should ever come back."Resolution answers "what finally happened"? It releases the suspense. Text 1 finally resolves when narrator tells that "I came BACK home". Similarly in text 2 I "took the one less traveled by" functions as resolution.

The last element in Labov's narrative analysis is coda, which is an optional element, found in free clauses and signals the end of story. Codas bridge the gap between the end of the story world and the present moment. As the narrator comes to present moment when he utters "let's see how it goes" and the closing conversation between the participants can also be considered as coda. Text 2 also brings the audience back to the point at which they entered the narrative with this instance "And that has made all the difference".

\section{Findings}

The analysis of above-mentioned texts shows the features of spoken and written language at both micro and macro level. It compares the features of both narratives. It also focuses on the features which are common in both spoken and written texts, especially when the written text follows the spoken context.

This phenomenon was ignored initially in linguistics, when the entire focus was on written language and spoken language was considered as formless and ungrammatical. However, recent research on the analysis of spoken discourse (Halliday, 1985, McCarthy, 1998) shows that spoken language also has a consistent structure and in many respects, it does have the language patterning as that of written English. Spoken language is the refection of written language. It derives from the written transcriptions of conversation. Apparently, it may appear 'formless' but beneath its surface, it is well organized and grammatically intricate. As the above analysis shows that both spoken and written discourse have consistent and describable structures, with different complexities reflecting the different functions of speech and writing. Therefore, language teachers should be aware of this relationship between 
UNIVERSITY OF CHITRAL JOURNAL OF LINGUISTICS AND LITERATURE

VOL. 5 | ISSUE I | JAN - JUNE | 2021

ISSN (E): 2663-1512, ISSN (P): 2617-3611

spoken and written language. They should encourage students to get to know the special qualities of spoken language and to accord 'validity' to both spoken and written formulations of language.

\section{Finale: Pedagogical Implications}

Discourse analysis describes how language is structured in different contexts of use. This approach, if adopted, by the teachers of foreign language learners will enable them to devise materials and strategies according to their students' needs. Thus, teachers provide different opportunities to second language learners to improve their language competency. Labov's modal of narrative analysis is an influential work in language teaching, which can help learners in improving their literary competence. As this modal describes the structure of spoken discourse and gives essential elements of a fully formed narrative, can be very beneficial in language teaching in multiple ways:

- It will give the foundation for the interpretation of the texts and their key elements of language.

- It will improve students' pragmatic and communicative competence.

- This narrative structure will develop in learners, the ability to look for patterns through discourse in language.

- Narratives impact language learning and acquisition process as they will give students exposure and motivation.

Thus, by adopting discourse based teaching strategies or following any languagebased analysis in the classroom, language competency can be developed which is the primary goal of the language teachers.

\section{References}

Afsar, A. (2008). A Discourse approach to spoken and written English and its implication for teaching of English as a second or foreign language. KASHMIR JOURNAL OF LANGUAGE RESEARCH, 11(1). 12. 
UNIVERSITY OF CHITRAL JOURNAL OF LINGUISTICS AND LITERATURE

VOL. 5 | ISSUE I | JAN - JUNE | 2021

ISSN (E): 2663-1512, ISSN (P): 2617-3611

Angelo O. Tubac, S. S. (2014). The Labovian functional categories in the written personal narratives. Retrieved from Scribd: http://www.scribd.com/doc/22445563/The-LabovianFunctional-Categories.

Bell, A. (1991). The language of news media. Oxford: Blackwell.

Frost, R. (2013). Robert frost poems. Retrieved from examplesinpoetry.com: http://www.examplesinpoetry.com/robert-frost-poems-examples.

Junqueira, L. D. (2010). Narrative analysis of oral personal experience across two languages and cultures: Brazilian Portuguese and American English. Retrieved fromhttp://acumen.lib.ua.edu/content/u0015/0000001/0000214/u0015_0000001_0000214 .pdf.

Labov, W. (1972). Language in the inner city:Studies in the Black English Vernacular. Philadelphia: University of Pennsyivania Press.

McCarthy, M. J. (1991). Discourse analysis for language teachers. Cambridge: Cambridge University Press.

Nordquist, R. (2014). Discourse analysis. Retrieved from About.com: http://grammar.about.com/od/d/g/discanalysisterm.htm.

William Labov, J. W. (1967). "Narrative analysis". Essays on the Verbal and Visual Arts, ed. J. Helm, 12-44. Seattle: University of Washington Press. Linguistics \& Literature, Pakistan. This article is an open access article distributed under the terms and conditions of the Creative Commons Attribution (CC BY) (http://creativecommons.org/licenses/by/4.0/). 